\title{
The Correlation Between Self-Concept and Anxiety of Finding a Partner in Young Adults in Urban Communities
}

\author{
Ivana Djajasaputra ${ }^{1}$ Debora Basaria $^{1 *}$
}

\author{
${ }^{1}$ Psychology Faculty, Tarumanagara University, West Jakarta, Indonesia \\ *Corresponding author. Email: deborab@fpsi.untar.ac.id
}

\begin{abstract}
Many young adults with single status have anxiety about finding a partner which is indicated by the increasing number of online dating application users. Many factors influence a person in finding a partner, one of which is self-concept. Self-concept is an individual's perspective on abilities and self-evaluation which is manifested in the form of behavior. Young adult individuals with positive and negative self-concepts both have the potential to feel anxious about finding a partner. Anxiety is an emotional feeling that is caused by a threat that comes from within or outside, both real and perceived, causing tension within. The purpose of this study was to examine the relationship between self-concept and anxiety in finding a partner in young adults. This study using Quantitative method. Sampling was conducted on November 16-30, 2020 using a purposive sampling technique involving 360 participants who have an age range of 20-30 years consisting of 250 women and 110 men. In this study, the correlation method and the Tennessee Self Concept Scale (TSCS) measurement tool by William H. Fitts were used and the State-Trait Anxiety Inventory (STAI) measurement tool by Spielberger, Gorsuch, and Lushene. Based on the analysis of respondent data using the Spearman correlation technique, it was found that there was a significant negative correlation between self-concept and anxiety of finding a partner in young adults. This indicates that the more positive individual self-concept makes the value of the anxiety variable lower and vice versa.
\end{abstract}

Keywords: Self-concept, partner anxiety, young adults

\section{INTRODUCTION}

Papalia and Martorell (20xx) [1] explained that including young adult individuals are those aged 20 years to 40 years. Individuals in the young adult stage have a duty to be independent and explore aspects of education, work, and love (Arnett, 2015) [2]. In the psychosocial development stage, according to Erikson, it is stated that young adults have a duty to establish romantic relationships accompanied by commitment or being isolated which is known as intimacy versus isolation (Santrock, 2019) [3].

According Tirto.id's data in September 2018, a professor from Yale University named Marcia Inhorn mentioned the phenomenon of delaying marriage among young people in the United States, Japan, China, Jordan, Rwanda, and Guatemala (Hasan, 2019) [4] . Quoted from Kompas, the Central Bureau of Statistics (BPS) in 2010 conducted a survey regarding the number of individuals with single status in Indonesia and obtained the results of an increase over the last 40 years and is estimated to continue to increase until 2020 (Krisiandi, 2018) [5]. BPS reported that in the past decade, as many as 1 in 14 individuals aged 30 39 years have not married (Krisandi, 2018).

Based on data obtained from Tempo.co (2020) [6], people who live in urban areas generally make marriage their second priority after career and education even though they are 35-40 years old. The National Population and Family Planning Board (BKKBN, 2017) [7] sets the ideal age for marriage for individuals in Indonesia is 21 to 25 years for women and 25 to 30 years for men. Quoted from The Conversation, a doctor named Karel Kasten Himawan from the University of Queensland Australia said that individuals with single status in Indonesia experience depressed conditions (Himawan, 2020) [8]. This difference in standards with the reality of the marital status of young adults creates feelings of anxiety about their ability to find partners.

Based on information obtained from Tirto.id, it is stated that online dating applications are widely used by young adults to find partners (Samudro, 2020) [9]. Data obtained from CNN News (2020) [10] stated that from February 2020 to March 2020, users of online dating applications such as Tinder, OkCupid, and Bumble have increased. In March 2020, the use of the online dating app Bumble in the United States increased by 8 percent. Tinder users in Brazil also experienced an increase of 15 percent, 19 percent in Germany, 20 percent in France and 25 percent in India. In Indonesia, users of online dating sites Tinder and OkCupid increased by 23 percent and 7 percent, respectively, from February 2020 to March 2020. 
Quoted from Bisnis.com, as many as $64 \%$ of online dating application users in Indonesia are Generation $\mathrm{Z}$ who are currently in the age range of 18-25 years (Lawi, 2020) [11]. These data indicate that the tendency of young adults to have a partner is quite high. Quoted from Tirto.id, young adults with high social anxiety stated that it is more fun to meet people through online dating applications with chat features than meeting in person or face to face (Nancy, 2019) [12]. The reason is because they can interact without having to show their real self.

Anxiety is a feeling of uneasy, nervousness, and fear that is unpleasant, but does not always interfere with an individual's ability to stay active in activities (King, 2014) [13]. Anxiety is a universal experience which can be felt by all individuals without being limited to space and time, as long as there are stressors that make individuals feel threatened, both real and in the form of imagination (Morrison \& Valfre, 2009) [14]. In the young adult stage, one of the factors that cause individual anxiety is the need to have a partner and have a life with a romantic relationship (Santrock, 2019).

Lodi et al. (2017) [15] explained self-concept as a personality factor related to anxiety. Individuals who understand their self-concept well tend to have low levels of anxiety, and vice versa (Lodi et al., 2017). Self-concept is generally defined as an individual's perception and belief in himself, which consists of various social categorizations that form self-labels such as gender, nationality, or profession (Gana, 2012) [16]. Self-concept is generally divided into positive self-concept and negative self-concept (Louw, 1998) [17]. Individuals with a positive self-concept are able to provide a good assessment of their quality, have a high level of self-confidence and a sense of confidence in their ability to get a partner (Louw, 1998). Conversely, individuals with negative self-concepts, have low levels of self-confidence, are prone to doubt, and have feelings of inadequacy in finding a partner (Louw, 1998).

Research conducted by McIntyre et al. (2017) [18] stated that the clarity of self-concept in each individual can predict a positive outcome in a romantic relationship. Individuals with high self-concept clarity are likely to produce positive relationships, including relationship quality, relationship satisfaction, commitment, and good conflict management. In the process of finding a partner, it cannot be denied that physical appearance is the main attraction. However, the same goals, vision and mission in life, hobbies, achievements, intelligence, and emotional intelligence are also considered to play an important role in the process of finding a partner. Young adult individuals with a positive self-concept view beauty not only based on the standards created by society, but also from all aspects that are owned in him with all the advantages and disadvantages.

Recently, beauty standards are controlled by social media and are based on judgments and comments from the public (Juniman, 2019) [19]. In fact, the definition of beauty is very dependent on the perceptions of each individual and is not only based on physical aspects but mental, financial, and spiritual aspects. However, currently there are many young adults who judge themselves not very well and feel insecure just because they feel they do not meet the standards of beauty that exist in society. This in turn creates anxious feelings in the individual about his ability to get a partner due to his own judgment.

As material that can support this research topic, researchers look for phenomena in the field by interviewing personally with ten young adults aged 20-40 years who use online dating applications. Researchers found different results regarding the self-concept of the respondents regarding the anxiety they feel in acquiring a partner. Individuals with both positive and negative self-concepts were found to have varying degrees of anxiety in finding a partner. It turns out that there are individuals with a positive self-concept who have high and low levels of anxiety in finding a partner. This individual feeling of anxiety then encourages them to use online dating applications with the aim of finding a partner (VT, FC, CA, KF, AJ, ID, SI, \& JLT, Personal communication, September 18, 2020; A\&R, Personal communications, November 5, 2020).

Research conducted by Proborini et al. (2019) [20] regarding anxiety in unmarried young adult women found that the level of individual anxiety varies, depending on self-confidence, independence and self-concept. An individual with a positive self-concept was found to have high levels of anxiety as well. Research conducted by Damayanti and Cahya (2020) [21] found a negative relationship between self-concept and anxiety about finding a life partner in early adult women where self-concept is a factor that can affect the level of anxiety in finding a life partner.

Several previous studies have explained that there is a negative relationship between self-concept and anxiety about partnering in young adult women. There is also research which states that anxiety in partnering is not always negatively related to self-concept. Based on differences from several previous research findings and background descriptions that have been described, researchers are interested in conducting research with subjects that focus not only on early adult women, but also young adults without differentiating gender regarding the relationship between self-concept and anxiety in young adults.

\subsection{Writing Structure}

This research consists of five parts in its writing. The first part is an introduction that contains background problems, problem formulations, research objectives, theoretical and practical research benefits, and writing systematics. The second part is a literature review which consists of theories related to anxiety and self concept. In addition, the second part also covers the research framework and hypothesis. The third section discusses research methods in terms of research participants, types of research, research settings and tools, variable measurement, research procedures, and data processing and analysis procedures. The fourth section discusses the research findings and data analysis. The fifth part is the last part which contains conclusions, discussions and suggestions. 


\section{LITERATURE REVIEW}

\subsection{Anxiety}

In the Big Indonesian Dictionary (KBBI, 2016) [22] it is stated that "kecemasan" (anxiety) comes from the root word "cemas" (anxious) and is defined as feeling worried or uneasy. According to Spielberger (1972) [23], anxiety is an individual's emotional state related to fear and tension that are felt in real terms and perceptions that cause feelings of worry. Anxiety can also be defined as an unpleasant emotional experience, involving concern about possible physical or psychological harm, increased physiological arousal, and motives for avoiding or running away from the situation that causes the anxiety (Leary \& Kowalski, 1997) [24].

Spielberger (1972) distinguishes two forms of anxiety into state anxiety and trait anxiety. State anxiety is defined as a temporary emotional state due to situational stress and will change over time which is usually marked by the appearance of a physiological reaction to the perceived anxiety or it can also occur when the individual is in a threatening situation (Spielberger, 1972). Furthermore, trait anxiety is the difference in individual tendencies in responding to stimuli / stressful situations that trigger anxiety and is usually described as a reflection of past experiences that form patterns of individual responses to similar stimuli / situations (Spielberger, 1972).

\subsection{Self-Concept}

This term was first put forward by William James where he distinguished it into two aspects, from self, namely "I" which refers to the individual as the subject and "Me" which refers to the individual as an object (Burns \& Dobson, 1984) [25]. "I" is known as the self that understands, while "Me" is the self that is understood (Burns \& Dobson, 1984). Individual experiences since childhood will influence and form relationships with other people, especially with those closest to them, which may affect how an individual assesses himself (Centi, 1993) [26]. Fitts (1971) [27] defines self-concept as an individual's perspective that forms a framework and guides in interacting.

Fitts (1971) said that self-concept consists of two dimensions, namely, internal and external dimensions. The internal dimension consists of three components which include: (1) identity, which is a label that is given by other people to individuals in an effort to build and describe their identity; (2) behavior, namely perceptions of individual behavior in everyday life; and (3) self-judging, namely labels or words from others that exist within the individual. The external dimension then consists of five aspects, including: (1) physical, namely one's perception of one's physical state; (2) moral-ethical, namely the individual's perception of himself based on the standard of consideration of moral and ethical values; (3) personal, namely the feelings or perceptions of an individual on his personal situation; (4) family, namely the feelings and self-esteem of an individual in his position as a family member, and (5) social, namely an individual's assessment of his interactions with other people and the wider environment around him..

\section{METHODS}

\subsection{Participants and Research Design}

Participants in this study were young adults with single status, male or female, and aged 20 to 30 years. The sampling technique was carried out using purposive sampling. The total number of participants in this study was 360 participants.

\subsection{Research Instrument}

\subsubsection{Anxiety}

In this study, the previous State-Trait Anxiety Inventory (STAI) questionnaire was used with 40 statements. The STAI questionnaire consists of 2 dimensions, (1) the State dimension and (2) the Trait dimension. The type of scale used is the Likert scale with four choices of answer numbers on the State Anxiety scale, namely (1) Not at all, (2) Somewhat, (3) Tending, and (4) Very. Meanwhile, the Likert scale answers for the Trait Anxiety scale consisted of (1) Not at all, (2) Somewhat, (3) Tending, and (4) Very. Reliability test results can be seen in Table 1 .

Table 1

The Reliability Testing Results of State-Trait Anxiety Inventory (STAI) Measurement

\begin{tabular}{|c|c|c|c|c|c|}
\hline \multirow[b]{2}{*}{$\begin{array}{l}\text { Dime } \\
\text { nsion }\end{array}$} & \multicolumn{2}{|c|}{ Alpha Cronbach } & \multicolumn{3}{|c|}{ Total Items } \\
\hline & $\begin{array}{l}\text { Before } \\
\text { Discardi } \\
\text { ng The } \\
\text { Item }\end{array}$ & $\begin{array}{l}\text { After } \\
\text { Discar } \\
\text { ding } \\
\text { The } \\
\text { Item }\end{array}$ & $\begin{array}{c}\text { Before } \\
\text { Discard } \\
\text { ing The } \\
\text { Item }\end{array}$ & $\begin{array}{c}\text { Discar } \\
\text { ded } \\
\text { Item }\end{array}$ & $\begin{array}{l}\text { After } \\
\text { Discar } \\
\text { ding } \\
\text { The } \\
\text { Item }\end{array}$ \\
\hline State & 0,927 & 0,927 & 20 & 0 & 20 \\
\hline Trait & 0.889 & 0.914 & 20 & 1 & 19 \\
\hline Total & & & 40 & 1 & 39 \\
\hline
\end{tabular}

\subsubsection{Self-Concept}

Tennessee Self-Concept Scale (TSCS) was used in this study. It aims to measure the individual self-concept developed by William H. Fitts in 1965. TSCS has been adapted and developed by Sri Rahayu Partosuwindo, et al in Indonesia in 1979, from Gadjah Mada University, 
Yogyakarta. TSCS consists of 100 statement items where 90 of them are used to measure the level of self-concept possessed by a person, while the remaining 10 statement items are used to measure the degree of individual openness in acknowledging and accepting criticism. The TSCS questionnaire consists of 2 dimensions, namely (1) internal dimensions, consisting of identity, judging, and behavior; and (2) external dimension, which consists of physical, moral-ethical, personal, family, social; and (3) selfcriticism. Reliability test results are presented in Tables $2 \&$ 3 below.

Table 2

The Reliability Testing Results of Tennessee Self-Concept Scale (TSCS) External Dimensions Measurement

\begin{tabular}{cccccc}
\hline & \multicolumn{3}{c}{ Alpha Cronbach } & \multicolumn{3}{c}{ Total Items } \\
\cline { 2 - 6 } Dimension & $\begin{array}{c}\text { Before } \\
\text { Discard } \\
\text { ing The } \\
\text { Item }\end{array}$ & $\begin{array}{c}\text { After } \\
\text { Discar } \\
\text { ding } \\
\text { The } \\
\text { Item }\end{array}$ & $\begin{array}{c}\text { Before } \\
\text { Discar } \\
\text { ding } \\
\text { The } \\
\text { Item }\end{array}$ & $\begin{array}{c}\text { Dis } \\
\text { car } \\
\text { ded } \\
\text { Ite } \\
\text { m }\end{array}$ & $\begin{array}{c}\text { After } \\
\text { Disca } \\
\text { rding } \\
\text { The } \\
\text { Item }\end{array}$ \\
\hline $\begin{array}{c}\text { Physical } \\
\text { Moral- } \\
\text { ethical }\end{array}$ & 0,577 & 0,734 & 18 & 6 & 12 \\
Personal & 0,815 & 0,822 & 18 & 1 & 17 \\
Family & 0.893 & 0.898 & 18 & 1 & 17 \\
Social & 0.823 & 0.829 & 18 & 1 & 17 \\
$\begin{array}{c}\text { Self } \\
\text { Criticism }\end{array}$ & 0.750 & 0.705 & 10 & 0 & 10 \\
\hline & Total & & 100 & 9 & 91 \\
\hline
\end{tabular}

Table 3

The Reliability Testing Results of Tennessee Self-Concept Scale (TSCS) Internal Dimensions

\begin{tabular}{|c|c|c|c|c|c|}
\hline \multirow[b]{2}{*}{ Dimension } & \multicolumn{2}{|c|}{$\begin{array}{c}\text { Alpha } \\
\text { Cronbach }\end{array}$} & \multicolumn{3}{|c|}{ Total Items } \\
\hline & $\begin{array}{c}\text { Befor } \\
\text { e } \\
\text { Disca } \\
\text { rding } \\
\text { The } \\
\text { Item }\end{array}$ & $\begin{array}{c}\text { After } \\
\text { Discar } \\
\text { ding } \\
\text { The } \\
\text { Item }\end{array}$ & $\begin{array}{c}\text { Before } \\
\text { Discar } \\
\text { ding } \\
\text { The } \\
\text { Item }\end{array}$ & $\begin{array}{c}\text { Disca } \\
\text { rded } \\
\text { Item }\end{array}$ & $\begin{array}{c}\text { After } \\
\text { Disca } \\
\text { rding } \\
\text { The } \\
\text { Item }\end{array}$ \\
\hline Identity & 0,809 & 0,841 & 30 & 3 & 27 \\
\hline Judging & 0.876 & 0.886 & 30 & 4 & 26 \\
\hline Behavior & 0,843 & 0,847 & 30 & 3 & 27 \\
\hline
\end{tabular}

\begin{tabular}{lccccc}
$\begin{array}{l}\text { Self } \\
\text { Criticism }\end{array}$ & 0.750 & 0.705 & 10 & 0 & 10 \\
\hline Total & & & 100 & 10 & 90 \\
\hline
\end{tabular}

\section{FINDINGS AND DISCUSSIONS}

\subsection{Normality test}

The normality test in this study was carried out using One Sample Kolmogorov Smirnov. The results of the normality test on the self-concept variable showed the value of $\mathrm{p}=$ $0.200>0.05$. Meanwhile, the variables of state anxiety and trait anxiety have $\mathrm{p}$ value $=0.064>0.05$ and $0.040<0.05$, respectively. It is concluded that the data on the self-concept and state anxiety variables are normally distributed, while the data on the trait anxiety variable are not normally distributed. The details of this analysis are fully presented in Table 4.

Table 4

Results of Normality Test on Self-Concept and Anxiety Variables

\begin{tabular}{|c|c|}
\hline Variable & $\mathrm{p}$ \\
\hline Self Concept & 0.200 \\
\hline State Anxiety & 0.064 \\
\hline Trait Anxiety & 0.040 \\
\hline
\end{tabular}

\subsection{Hypothesis Testing}

The correlation test between self-concept and anxiety in finding a partner was done using the Spearman Rank Correlation. This is due to the presence of one variable data that is not normally distributed. The correlation test results showed a negative and very significant relationship between self-concept and the state anxiety dimension with a value of $r=-0.649, p=0.00<0.05$. The same result also applies to the correlation between self-concept and the dimensions of Trait's anxiety which shows a negative and very significant relationship with $\mathrm{r}=-0.676, \mathrm{p}=0.00<0.05$.

\subsection{Additional Analysis Test}

\subsubsection{Differences in state anxiety based on gender}

The results of the descriptive analysis of anxiety state in terms of gender found that women had a greater mean, namely 188.84 . Based on the results of different tests using 
the Mann Whitney $\mathrm{U}$, the $\mathrm{U}$ value was $11,666, \mathrm{p}=0.022$ $<0.05$. Therefore it can be concluded that in terms of gender, there are differences in state anxiety.

\subsubsection{Differences in self-concept based on friend ownership}

The results of the self-concept descriptive analysis in terms of ownership of friends found that participants who had friends had a greater mean, namely 184.30. Based on the results of different tests using the Mann Whitney $U$, the $U$ value obtained was $1.613, \mathrm{p}=0.002<0.05$. Thus it can be concluded that there are differences in self-concept in terms of ownership of friends.

The findings of this study are in line with previous research conducted by Damayanti and Cahya (2020) which found that self-concept and anxiety in having a partner have a negative relationship. Although there were differences in the sex of participants in previous studies, the results obtained did not affect the relationship between selfconcept and anxiety.

Based on the results of the correlation test, the self-concept variable with each dimension of anxiety has a very significant negative relationship. It was found that the correlation value between the self-concept variable and the trait anxiety dimension was higher than the state anxiety. This is because the self-concept is part of an individual's self that develops over time and begins to settle in adulthood (Papalia \& Martorell, 20xx). This is in line with trait anxiety which does not fluctuate from time to time, but is stable and is not influenced by the situation when the individual is faced with a problem. In other words, it can be said that these two variables tend not to change and become part of an individual's personality.

In this study, the average participant who experienced state anxiety about getting a partner was only a few. McCrae and Costa (in Feist \& Feist, 2009) [28] say that self-concept is part of a person's personality when they enter adulthood. Meanwhile, state anxiety is a personality trait that is not permanent. It can be concluded that if young adults have high state anxiety, their self-concept is not always low but depends on their current circumstances. So the correlation is not as big as between the self-concept variable and trait anxiety, both of which are part of the personality that tends to stay.

Participants in this study were dominated by those aged 21 years, working as students, and involved in the community. They still have the duty and responsibility to complete their education, are active in building relationships, and are active in society. Therefore, the negative anxiety felt in getting a partner tends to be low because the need for a partner may not be the priority..

The findings based on the results of data analysis are that the eight dimensions of self-concept in the participants have varying values, their dominance is with a fairly high value. This shows that the average self-concept of participants in young adults with single status can be said to be positive. William (1974 in Rakhmat, 2011) [29] explains that individuals with a positive self-concept can see the problems faced as challenges, not threats or obstacles.
From the additional data analysis, it was found that there were differences in state anxiety based on gender. These results are in line with the results of research conducted by Ruginski et al. (2018) [30] who found that anxiety states are generally more common in women than in men. This is what makes women more likely to experience state anxiety when they are faced with a task. Quoted from The Guardian, based on research conducted by Remes from Cambridge University in 2016, it is known that women are more prone to experiencing anxiety than men (Davis, 2016) [31].

In this study, different tests were also carried out on selfconcept variables in terms of the ownership of friends. From this test, it was found that there were differences in selfconcept related to the ownership of friends. The results of the additional data analysis show that there is a significant difference in the self-concept variable in terms of the ownership of friends. The findings of this study are in line with the results of research conducted by Ananda and Sawitri (2015) [32] which state that there is a difference between self-concept in adolescents who have friends with adolescents who do not. This finding is supported by developmental theory which states that self-concept is formed in adolescence, when individuals begin to make peer groups their role models (Burns \& Dobson, 1984). Therefore, the role of friends is quite important in shaping.

\section{CONCLUSIONS}

Referring to the results of the study, it was found that there was a relationship between self-concept and anxiety about finding a partner in young adults. The two variables are negatively related which can be explained that if the value of the participant self-concept variable is positive, then the value of the anxiety variable will be low. Likewise, the negative self-concept variable value of the participants will create a high anxiety variable value. This finding can be seen from the similarity of the research hypothesis with the results of the main data analysis. Thus it is concluded that the hypothesis in this study is accepted.

\section{REFERENCES}

[1] D. E. Papalia, dan G. Martorell, (20xx). Experience human development (13th ed.). McGraw-Hill.

[2] J. J. Arnett, (2015). Dewasa muda: The winding road from the late teens through the twenties (2nd ed.). Oxford.

[3] J. W. Santrock, (2019). Life-span development (17th ed.). McGraw-Hill.

[4] A. M. Hasan, (2019, Januari 11). 'Waithood' \& Mengapa Jomblo Usia 30-an Kini Jadi Fenomena Global. Tiro.id. https://tirto.id/waithood-mengapa-jomblo-usia30an-kini-jadi-fenomena-global-dd5V

[5] Krisiandi. (2018, Februari, 18). Lajang indonesia dianggap masalah dan hadapi tekanan sosial. Kompas. 
https://sains.kompas.com/read/2018/02/18/174448623/laja ng-indonesiadianggap-masalah-dan-hadapi-tekanansosial? page $=$ all

[6] Tempo.co. (2020, Januari 4). Masih melajang menjelang usia 40 sudah tidak ingin menikah?. https://gaya.tempo.co/read/1291023/masih-melajangmenjelangusia-40-sudah-tak-ingin-menikah

[7] Badan Kependudukan dan Keluarga Berencana Nasional. (2017, Maret 6). BKKBN: Usia pernikahan ideal $21-25$ tahun. BKKBN.

https://www.bkkbn.go.id/detailpost/bkkbn-usiapernikahan-ideal-21-25-tahun

[8] K., K. Himawan, (2020, Maret 19). Analisis: lajang bukan berarti tidak mau menikah, menikah juga bukan berarti karena tidak mau melajang. The Conversation. https://theconversation.com/analisis-lajang-bukan-berartitidak-mau-menikah-menikah-juga-bukan-berarti-karenatidak-mau-melajang-133517

[9] A. Samudro, (2020, Januari 28). Cara menghapus akun tinder secara permanen. Tirto.id. https://tirto.id/caramenghapus-akun-tinder-secara-permanen-euJn

[10] Cable News Network Indonesia. (2020, April 2). Wabah Corona bikin aplikasi kencan online laris manis. https://www.cnnindonesia.com/teknologi/2020040214474 7-185- 489624/wabah-corona-bikin-aplikasi-kencanonline-laris-manis

[11] G. F. K. Lawi, (Agustus, 06, 2020). Pembatasan sosial, kencan online di tinder kian popular. Bisnis.com. https://lifestyle.bisnis.com/read/20200806/54/1275842/pe mbatasan-sosialkencan-online-di-tinder-kian-populer

[12] Y. Nancy, (2019, Agustus 12). Studi sebut candu aplikasi kencan indikasi dari social anxiety. Tirto.id. https://tirto.id/studi-sebut-candu-aplikasi-kencanindikasidari-social-anxiety-ef9m

[13] L. A. King, (2014). The science of psychology: An appreciative view (3rd ed.). McGraw-Hill.

[14] M. Morrison, \& Valfre. (2009). Foundations of mental health care (4th ed.). Elsevier Health Sciences.

[15] J. L. Smith,, \& K. G. DeMaree, (Eds.). (2017). SelfConcept Clarity. Springer.

[16] K. Gana, (2012). Psychology of self-concept. Nova Science Publisher.

[17] D. A. Louw, (1998). Human development. Pearson.

[18] K. P. McIntyre, B. A. Mattingly, \& G. W. Lewandowski, (2017). Self-concept clarity and romantic relationships. Self-Concept Clarity, 107-124. https://doi:10.1007/978-3-319-71547-6_6

[19] P. T. Juniman, (2019, Februari, 22). Dilema beauty 4.0 saat standar cantik ada di tangan netizen. CNN. https://www.cnnindonesia.com/gayahidup/2019021609562 5-277-369797/dilema-beauty-40-saat-standar-cantikadadi-tangan-netizen

[20] R. Proborini, G. S. Lestari, \& K. Khairani, (2019). Kecemasan pada wanita yang telat menikah dalam perspektif person centered therapy. Jurnal Psikologi Malahayati, 1(2). https://doi.org/10.33024/jpm.v1i2.1874_

[21] E. L. Damayanti, \& E. Cahya, (2020). Hubungan Antara Konsep Diri Dengan Kecemasan Memperoleh Pasangan Hidup Pada Wanita Dewasa Awal. NERSMID: Jurnal Keperawatan dan Kebidanan, 3(1), 67-75.

[22] Kementerian Pendidikan dan Budaya. (2016). Kecemasan. Retrieved from https://kbbi.kemdikbud.go.id/entri/kecemasan

[23] C. D. Spielberger, (1972). Anxiety: Current trends in theory and research. Academic Press.

[24] M. R. Leary, dan R. M. Kowalski, (1997). Social anxiety. Guilford Press.

[25] R. B. Burns, \& C. B. Dobson, (1984). The self-concept. Introductory Psychology, 473-505. https://doi.org/10.1007/978-94-011-6279-1_13

[26] J. P. Centi, (1993). Mengapa Rendah Diri?. Kanisius.

[27] W. H. Fitts, (1971). The Self Concept and SelfActualization. Western Psychological Service.

[28] J. Feist, \& G. J. Feist, (2009). Theories of personality (7th ed.). McGraw Hill.

[29] J. Rakhmat, (2011). Psikologi Komunikasi. Remaja Rosadakarya.

[30] I. T. Ruginski, J. K. Stefanucci, \& S. H. C. Regehr, (2018). State anxiety influences sex differences in spatial learning. Spatial Cognition XI, 244-257. https://doi.org/10.1007/978-3-319-96385-3_17

[31] N. Davis, (2016, Juni, 6) Women twice as likely as men to experience anxiety, research finds. The Guardian. https://www.theguardian.com/society/2016/jun/06/womentwice-as-likely-as-men-to-experience-anxiety-researchfinds\#: :text=Women $\% 20$ twice $\% 20$ as $\% 20$ likely $\% 20$ as $\% 2$ 0men\%20to\%20xperience $\% 20$ anxiety $\% 2 \mathrm{C} \% 20$ research $\% 20$ finds,-

This\%20article\%20is\&text=Women $\% 20$ are $\% 20$ nearly $\% 2$ 0twice $\% 20$ as,of\%20studies $\% 20$ into $\% 20$ the $\% 20$ condition.

[32] D. R. T. Ananda, \& D. R. Sawitri, (2015). Konsep diri ditinjau dari dukungan teman sebaya pada remaja di panti asuhan qosim al-hadi semarang. Empati, 4(4), 298-303. 